Nhóm răng trám thành công và nhóm răng đã điều trị tủy tốt đã làm chụp đều không tiêu chân răng do viêm. Điều này chứng tỏ nếu các răng sâu được kiểm soát và điều trị đúng thì sẽ không có hiện tượng tiêu viêm chân răng xảy ra.

\section{KẾT LUẬN}

Tỉ lệ tiêu viêm chân răng hàm sữa ở trẻ 5-8 tuổi đến khám ở Viện Đào tạo Răng Hàm Mặt và Bệnh viện Răng Hàm Mặt Trung Ương Hà Nội là $23,33 \%$. Nhóm các răng sâu có tổn thương tủy răng trong nghiên cứu có tỉ lệ tiêu viêm chân răng cao nhất trong khi nhóm các răng đã điều trị tủy tốt được làm chụp và nhóm răng trám thành công không thấy có hiện tượng tiêu viêm chân răng. Nghiên cứu của chúng tôi mới áp dụng trên nhóm trẻ ở độ tuổi từ 5-8 tuổi, nghiên cứu tiếp theo có thể mở rộng độ tuổi, so sánh giữa các độ tuổi khác nhau đồng thời khảo sát ở các cơ sở khám chữa bệnh khác và xác định các yếu tố liên quan đến tình trạng tiêu viêm chân răng sữa.

Lời cảm ơn. Nhóm nghiên cứu xin bày tỏ lời cảm ơn tới các bệnh nhân, phụ huynh trẻ đã tham gia nghiên cứu và Viện Đào tạo Răng Hàm
Mặt- Trường Đại học Y Hà Nội, Bệnh viện Răng Hàm Mặt Trung Ướng Hà Nội đã hỗ trợ để thực hiện nghiên cứu này.

\section{TÀI LIÊU THAM KHẢO}

1. Vieira-Andrade RG, Drumond $C L$, Alves LPA, Marques LS, Ramos-Jorge ML. Inflammatory root resorption in primary molars: prevalence and associated factors. Brazilian Oral Research. 2012;26(4):335-340. doi:10.1590/S1806 83242012000400009.

2. Santos BZ, Bosco VL, Silva JYB da, Cordeiro MMR. Physiological and pathological factors and mechanisms in the process of root resorption in primary teeth. RSBO (Online). 2010;7(3):332-339.

3. Cardoso M, Rocha MJ de C. Identification of factors associated with pathological root resorption in traumatized primary teeth. Dent Traumatol. 2008;24(3):343-349.doi:10.1111/j.1600-9657. 2007.00554.

4. Mulia DP, Indiarti IS, Budiarjo SB. Effect of root resorption of primary teeth on the development of its permanent successors: An evaluation of panoramic radiographs in 7-8 yearold boys. J Phys: Conf Ser. 2018;1073:032015. doi:10.1088/1742-6596/1073/3/032015.

5. Đoàn Quốc Hưng, Nguyê̂n Đăng Vững và Đỗ Thị Thanh Toàn. Phương Pháp Nghiên Cứu Trong Y Sinh Học. Nhà xuất bản Y học; 2018.

\title{
MỐI LIÊN QUAN CỦA CÁC YẾU TỐ NGUY CO' VớI BỆNH VIÊM QUANH RĂNG MẠN TÍNH
}

TÓM TẮT

Mục tiêu: Nghiên cứu nhằm xác định mối liên quan của các yếu tố nguy cơ như sự có mặt của một số vi khuẩn đặc hiệu trong túi quanh răng, tình trạng hút thuốc lá, tuổi, giới... với tình trang phá hủy vừng quanh răng trên một nhóm người Việt nam. Đối tượng và phương pháp: Nghiên cứu bênh chứng trên 113 đối tượng tuổi từ 20 đến 65 gồm 75 bệnh nhân $V Q R$ và 38 người có vùng quanh răng khỏe mạnh. Các đối tượng được khám toàn bộ hai hàm, ghi nhân các chỉ số lầm sàng, tình trang hút thuốc lá và lấy mẫu mảng bám dưới lợi. Các mẫu mảng bám được xét nghiệm vi khuẩn gây bệnh bằng phương pháp PĆR và nuôi cấy phân lập. Các chỉ số lấm sàng và kết quả xét nghiệm vi khuẩn được phân tích bằng phần mềm thống kê Y học Epi Info 6.04. Kết quả: Có mối liên hệ chặt chẽ giữa sự có mặt của A.actinomycetemcomitans T.forsythensis, F. Nucleatum, P.intermedia và tình

*Bênh viện Răng Hàm Mặt TU Hà Nội

*Viên Y Dước lầm sàng 108

Chịu trách nhiệm chính: Nguyễn Thị Hồng Minh

Email: lethuhai3009@gmail.com

Ngày nhận bài: 22/3/2021

Ngày phản biên khoa hoc: 3/5/2021

Ngày duyệt bài: 19/5/2021 trạng hút thuốc lá với OR (độ tin cậy 95\%) lân lượt là 7,$50 ; 3,31 ; 2,37$ và 2,17 . Tình trạng hút thuốc lá có mối liên quan chặt chẽ với tình trạng mất bám dính quanh răng lâm sàng và tình trang tích tụ mảng bám răng . Có mối liên quan chặt chẽ giữa độ tuổi trên 35 với bệnh viêm quanh răng ở nhóm đối tượng nghiên cứu với OR (độ tin cậy $95 \%$ ) là 4,28 và $p<0,01$. Kết luân: Các yếu tố nguy cơ như sự có mặt của một số vi khuẩn đặc hiệu trong túi quanh răng, tình trạng hút thuốc lá, tuổi... có liên quan chặt chễ với tình trạng tiến triển của bệnh viêm quanh răng. Những yếu tố này có thể được coi là yếu tố chỉ điểm cho mức độ trầm trong của bệnh VQR và được sử dụng để tiên lượng cho kết quả điều trị bệnh VQR.

Tư khóa: Viêm quanh răng mạn tính, yếu tố nguy cơ

\section{SUMMARY}

\section{THE RELATION BETWEEN RISK FACTORS WITH CHRONIC PERIODONTITIS}

Objectives: to determine the relation between risk factors such as the present of some putative bacteria in sub- gingival plaque, tobacco smoking, age, sex and periodontitis status in one Vietnamese group. Methods: it was case-control study that carried out in 113 subjects with the age of 20 to 75 included 75 periodontitis patients and 38 healthy periodontal status. Based on full mouth examination, 
clinical criteria were recorded and sub-gingival plaque samples were collected. PCR and culture method was used to determine the present of the putative micro pathogens in samples. The result was analyzed by medical software. Results: There was the closed relation between the present of A.actinomycetemcomitans, T.forsythensis, F. nucleatum và P.intermedia and smoking with $\mathrm{OR}(\mathrm{CI}$ $95 \%$ ) was 7,$50 ; 3,31 ; 2,37$ và 2,17 , respectively. The age over 35 years old had firmly relation with periodontitis (OR was 4,28 and $p<0,01$ ). Conclusions: The risk factor as smoking, age effect directly to micro flora in sub-gingival plaque that do effect the initiation and progression of periodontitis. Those factors could be considered markers for the serious of periodontitis and was using for prediction the outcome of treatment.

Keywords: Chronic periodontitis, risk factors

\section{I. ĐĂT VẤN ĐỀ}

Viêm quanh răng (VQR) là một bệnh trong những bệnh răng miệng thường gặp ở Việt Nam và là nguyên nhân hàng đầu gây mất răng ở lứa tuổi trên 45. Từ lâu, người ta đã biết đây là một bệnh đa nguyên nhân, trong đó yếu tố bệnh căn chính là vi khuẩn trong mảng bám dưới lợi và đáp ứng miễn dịch của cơ thể. Biểu hiên và tiến triển của bênh bị ảnh hưởng của rất nhiều yếu tố như đáp ứng miễn dịch của từng cá thể, yếu tố xã hội, thói quen ăn uống và vệ sinh răng miệng, các yếu tố toàn thân, yếu tố di truyền, các yếu tố tại chố, thành phần vi khuẩn trong mảng bám răng và các yếu tố nguy cơ khác. Nhiều nghiên cứu mô tả cắt ngang, phân tích đa biến đã được tiến hành để tìm kiếm mối liên quan giữa yếu tố nguy cơ và mức độ và tình trạng nặng của bệnh quanh răng. Các tác giả đã đưa ra một số yếu tố nguy cơ của viêm quanh răng như: giới, tuổi, điêu kiện kinh tế, trình độ văn hóa, bệnh toàn thân, hút thuốc lá...(1). Đã có nhiều tác giả trên thế giới báo cáo về mối liên quan của các yếu tố nguy cơ này với tình trạng bệnh $V Q R$, tuy nhiên ở Việt Nam những nghiển cứu về vấn đề này còn rất hạn chế. Mục tiêu của nghiên cứu này là đánh giá mối liên quan của các yếu tố nguy cơ là sự có mặt của một số vi khuẩn đặc hiệu trong túi quanh rằng tuổi, giới và tình trạng hút thuốc lá với tình trạng viêm quanh răng ở một nhóm người Việt Nam.

\section{II. ĐỐI TƯỢNG VÀ PHƯƠNG PHÁP NGHIÊN CỨU}

2.1 Đối tượng nghiên cứu: Nghiên cứu được tiến hành trên 113 bệnh nhân tại Khoa Nha chu Bệnh Viện Răng Hàm Mặt Trung ương Hà Nội trong độ tuổi từ 20 đến 65 trong thời gian từ tháng 5 đến tháng 11 năm 2009.

2.2 Thiết kế nghiên cứu: Nghiên cứu bệnh chứng mô tả cắt ngang.

\subsection{Chọn mẫu và thu thập số liệu:}

2.3.1. Chọn mẫu: 113 đổi tượng, được chia làm 2 nhóm.

*Nhóm 1 (nhóm VQR): gồm 75 bệnh nhân được chẩn đoán là Viêm quanh răng mạn tính thể vừa và nặng dựa vào tiêu chuẩn của Viện hàn lâm Nha chu Mỹ (1998) (2)

Các đối tượng trong nhóm này đều phải đạt các tiêu chuẩn sau:

- Có ít nhất 20 răng trên cung hàm với ít nhất 2 túi quanh răng sâu trên $3 \mathrm{~mm}$ trong hai vùng lục phân, có hiện tượng chảy máu khi thăm khám.

- Có hình ảnh tiêu xương ổ răng trên phim X-quang.

- Không được điều trị bệnh vùng quanh răng hoặc điều trị bằng kháng sinh trong vòng 6 tuần trước khi lấy mẫu.

*Nhóm 2 (nhóm chứng): gồm 38 bệnh nhân đến kiểm tra răng miệng, làm vệ sinh răng miêng hoăc các điều tri khác không phải là điều trị bệnh vùng quanh răng có các tiêu chuẩn sau:

- Có tình trạng lợi từ bình thường đến có biểu hiện viêm nhe.

- Không được mất quá 1 răng trong mỗi vùng lục phân (trừ răng số 8 ).

- Không có túi lợi bệnh lý, không có biểu hiện mất bám dính quanh răng.

- Trên phim X-quang: khoảng cách từ ranh giới men-cement đến đỉnh mào xương ổ răng $\leq$ $2 \mathrm{~mm}$ ở tất cả các vị trí gần.

2.3.2. Ghi nhận các chỉ số lâm sàng: Dựa trên cơ sở khám toàn bộ 2 hàm, các chỉ số lâm sàng sau được ghi nhân:

- Tình trạng cá nhần: tuổi, giới

- Tình trạng hút thuốc lá

- Đô sâu túi quanh răng

- Độ mất bám dính quanh răng lâm sàng

- Chỉ số chảy máu khi thăm khám

- Chỉ số lợi

- Tình trang vệ sinh răng miệng thể hiện bằng chỉ số tích tụ mảng bám

2.3.3. Lây mẫu mảng bám dưới lợi: Các mẫu mảng bám dưới lợi được lấy từ túi quanh răng sâu nhất trên bệnh nhân VQR mạn tính (nhóm 1 ) và từ rãnh lợi mặt ngoài răng số 6 hàm trên bên phải ở nhóm đối tượng có vùng quanh răng khỏe mạnh (nhóm 2). Các mẫu mảng bám được lấy bằng bốn côn giấy vô trùng đặt song song vào túi lợi trong 30 giây và chuyển ngay vào môi trường vận chuyển yếm khí và giữ ở nhiệt độ âm $20^{\circ} \mathrm{C}$ cho đến khi xét nghiệm.

2.3.4. Phương pháp chuẩn bị mẫu và xác định vi khuẩn: PCR: Các mẫu mảng bám được xử lý và chạy PCR tại Labo Vi sinh, Trường 
Đại học Y Hà Nội với 5 mẫu ADN chuẩn của 5 chủng chuẩn (Porphyromonas gingivalis ATCC 33277, Prevotella intermedia ATCC 25611, Tannerella forsythensis ATCC 43037, Fusobacterium nucleatum ATCC 10953) cho các vi khuẩn cần tìm do GS. Andrej Weintraub, khoa LabMed, viện Karolinska, Thụy Điển cung cấp và
PCR được thực hiện trên máy GienAmp PCR System 9700 AB (Applied iossystems, USA).

Nuôi cấy phân lập ky khí: Được thực hiện tại khoa vi sinh, Bệnh viện Bạch Mai, Hà Nội.

2.4. Xử lý số liệu: Số liệu nghiên cứu được xử lý trên phần mềm Epi Info 6.04.

\section{KẾT QUẢ NGHIÊN CỨU}

Bảng 3.1. Phân bố đôi tượng nghiên cứu theo tuổi, giới và tình trạng hút thuốc lá:

\begin{tabular}{|c|c|c|c|c|}
\hline & $\begin{array}{c}\text { Tống số } \\
(\mathbf{N}=\mathbf{1 1 3})\end{array}$ & $\begin{array}{c}\text { Nhóm bềnh } \\
(\mathbf{n = 7 5 )}\end{array}$ & $\begin{array}{c}\text { Nhóm chứng } \\
(\mathbf{n}=\mathbf{3 8})\end{array}$ & Giá trị p \\
\hline Tuổi $(\mathrm{năm}, \mathrm{X} \pm \mathrm{SD})$ & $43,1 \pm 8,2$ & $46,1 \pm 8,5$ & $37,1 \pm 8,7$ & $<0,05$ \\
\hline Giới $\mathrm{n}(\%): \mathrm{Nam}$ & $72(63,7 \%)$ & $50(66,7 \%)$ & $22(57,9 \%)$ & $>0,005$ \\
Nữ & $41(36,3 \%)$ & $25(33,3 \%)$ & $16(42,1 \%)$ & $>0,005$ \\
\hline Hút thuốc lá: Không hút & $77(68,1 \%)$ & $46(61,3 \%)$ & $31(81,6 \%)$ & $<0,05$ \\
Đang hút & $36(31,9 \%)$ & $29(38,7 \%)$ & $7(18,4 \%)$ & $<0,05$ \\
\hline
\end{tabular}

Bảng trên cho thấy các đối tượng nghiên cứu có độ tuổi phân bố rải rác từ 20 đến 65 tuổi, tập trung chủ yếu ở độ tuổi 35 - 55, trung bình là $43,1 \pm 8,2$ tuổi. Trong đó, tuổi trung bình của nhóm bệnh là $46,1 \pm 8,5$ tuổi và nhóm chứng là $37,1 \pm 8,7$ tuổi. Sự khác biệt về tuổi giữa hai nhóm có ý nghĩa thống kê $(p<0,05)$.
Trong số 113 đối tượng nghiên cứu, có 36 người hút thuốc lá chiếm tỷ lệ 31,9 \%, trong đó nhóm bệnh có 29 người chiểm tỷ lệ $38,7 \%$ và nhóm chứng có 7 người chiếm tỷ lệ $18,4 \%$. Sự khác biệt về tình trạng hút thuốc lá của đổi tượng nghiên cứu giữa hai nhóm có ý nghĩa thống kê với $\mathrm{p}<0,05$.

Bảng 3.2. Môi liên quan của sự có mặt của các vi khuẩn gây bệnh với tình trạng VQR

\begin{tabular}{|c|c|c|c|c|}
\hline \multirow[b]{2}{*}{ Loại VK } & \multicolumn{4}{|c|}{ Tỷ lệ dương tính các VK theo nhóm $(\mathrm{N}=113)$} \\
\hline & $\begin{array}{c}\text { Nhóm bệnh } \\
(\mathrm{N}=75)\end{array}$ & $\begin{array}{c}\text { Nhóm chứng } \\
(\mathrm{N}=38)\end{array}$ & $\begin{array}{c}\text { OR } \\
\text { (độ tin cậy 95\%) }\end{array}$ & Giá trị p \\
\hline $\mathrm{Aa}$ & $100 \%$ & $0 \%$ & - & $<0,05$ \\
\hline $\mathrm{Pg}$ & $0 \%$ & $0 \%$ & - & $>0,05$ \\
\hline Tff & $88,7 \%$ & $11,3 \%$ & $8,95(3,07-7,43)$ & $<0,01$ \\
\hline Fn & $91,7 \%$ & $8,3 \%$ & $6,36(0,79-136,97)$ & $<0,05^{*}$ \\
\hline $\mathrm{Pi}$ & $100 \%$ & $0 \%$ & - & $>0,05$ \\
\hline
\end{tabular}

*:hiệu chỉnh Fisher cho test khi bình phương; viêm quanh răng với OR là 8,95; có nghĩa là (-): không xác định

Bảng 3.2 cho thấy mối liên quan giữa sự có mặt của các loại vi khuẩn nghiên cứu với bệnh viểm quanh răng, thể hiện qua tỷ số nguy cơ $O R$ với độ tin cậy 95\%.

Kểt quả phân tích hồi quy logic cho thấy $\mathrm{T}$. forsythensis có mối liên quan rất chặt với bệnh những người có $T$. Forsythensis trong túi quanh răng sẽ có nguy cơ mắc VQR cao hơn người không có vi khuẩn này gần 9 lần.

Kết quả này cũng tương tự với F.nucleatum với OR là 6,36. Tuy nhiên, chưa thây mối tương quan giữa các vi khuẩn khác với bệnh viêm quanh răng ở nhóm đối tượng nghiên cứu.

Bảng 3.3 Môi liên quan giữa tình trạng hút thuốc lá với sự có mặt của của vi khuẩn nghiên cứu trong các mấu mảng bám dưới lợi

\begin{tabular}{|c|c|c|c|c|c|c|c|c|c|c|}
\hline \multirow{2}{*}{$\begin{array}{l}\text { Tình trang } \\
\text { hút thuốc }\end{array}$} & \multicolumn{2}{|c|}{ Tf $(n, \%)$} & \multicolumn{2}{|c|}{ Fn $(n, \%)$} & \multicolumn{2}{|c|}{$\mathrm{Pi}(\mathrm{n}, \%)$} & \multicolumn{2}{|c|}{ Aa $(n, \%)$} & \multicolumn{2}{|c|}{$\operatorname{Pg}(n, \%)$} \\
\hline & $(+)$ & $(-)$ & $(+)$ & $(-)$ & $(+)$ & $(-)$ & $(+)$ & $(-)$ & $(+)$ & $(-)$ \\
\hline Không hút & $29(37,7)$ & $48(62,3)$ & $6(7,8)$ & $71(92,2)$ & $1(1,3)$ & $76(98,7)$ & $2(2,6)$ & $75(97,4)$ & $0(0,0)$ & $75(100,0)$ \\
\hline Đang hút & $24(66,7)$ & $12(33,3)$ & $6(16,7)$ & $30(83,3)$ & $1(2,8)$ & $35(97,2)$ & $6(16,7$ & $30(83,3)$ & $0(0,0)$ & $38(100,0)$ \\
\hline $\mathrm{P}$ & &, 05 & & 0,05 & & 0,05 & & 0,05 & & 0,05 \\
\hline $\begin{array}{c}\text { OR } \\
(95 \% \mathrm{CI})\end{array}$ & $(1,33$ & $\begin{array}{l}31 \\
-8,38)\end{array}$ & $\begin{array}{r}2 \\
(0,06 \\
\end{array}$ & $\begin{array}{l}37 \\
-9,30)\end{array}$ & $\begin{array}{r}2 \\
(0-\end{array}$ & $83,72)$ & $\left(1,24^{7}\right.$ & $\begin{array}{l}50 \\
58,13)\end{array}$ & & - \\
\hline
\end{tabular}

Bảng 3.3 cho thây mối liên quan giữa tình trạng hút thuốc lá và sự có mặt của các vi khuẩn nghiên cứu trong túi quanh răng. Có mối liên hệ chặt chẽ giữa sự có mặt của A.actinomycetemcomitans và tình trạng hút thuốc lá với OR (độ tỉn cậy $95 \%$ ) là 7,50 . Cũng có mối quan hệ này đối với T.forsythensis, $F$. Nucleatum và P.intermedia nhưng không chặt chẽ bằng (OR 
lần lượt là 3,$31 ; 2,37$ và 2,17).

Bảng 3.4. Mối liên quan giữa tình trạng lợi và hút thuốc lá

\begin{tabular}{|c|c|c|c|c|}
\hline \multirow[b]{2}{*}{ Hút thuốc lá } & \multicolumn{2}{|c|}{ Tình trạng lợi ( $\mathbf{N}=113)$} & \multirow[b]{2}{*}{$\begin{array}{c}\text { Giá trị } \\
\text { p }\end{array}$} & \multirow{2}{*}{$\begin{array}{c}\text { OR* } \\
\text { (CI 95\%) }\end{array}$} \\
\hline & $\begin{array}{l}\text { Khỏe mánh } \\
\text { (Mã số } 0+1)\end{array}$ & $\begin{array}{c}\text { Bệnh lý́ } \\
\text { (Mã số 2+3) }\end{array}$ & & \\
\hline Không hút $\mathrm{n}(\%)(\mathrm{N}=77)$ & $15(19,5)$ & $62(80,5)$ & $<0,05$ & 2,66 \\
\hline Đang hút $\mathrm{n}(\%)(\mathrm{N}=36)$ & $3(8,3)$ & $33(91,7)$ & $<0,05$ & $(0,65-12,67)$ \\
\hline
\end{tabular}

*Phân tích hồi quy logich

Mối liên quan giữa tình trạng lợi và tình trạng hút thuốc lá của các đối tượng nghiên cứu được thể hiện trong bảng 3.3. Kết quả cho thây tỷ lệ viêm lợi ở nhóm đang hút thuốc cao hơn nhóm không hút ở mức có ý nghĩa thống kê $(p<0,05)$, nghĩa là người hút thuốc lá có tỷ lệ viêm lợi cao hơn người không hút. Có mối liên quan giữa tình trạng viêm lợi và người hút thuốc lá với OR (độ tin cậy $95 \%$ ) là 2,66 (0,65-12,67).

Bảng 3.5. Môi liên quan giữa tình trạng tích tụ MBR và hút thuốc

\begin{tabular}{|c|c|c|c|c|}
\hline \multirow[b]{2}{*}{ Hút thuốc lá } & \multicolumn{2}{|c|}{ Tình trạng tích tụ mảng bám răng } & \multirow{2}{*}{$\begin{array}{c}\text { OR* } \\
(95 \% \mathrm{CI})\end{array}$} & \multirow[b]{2}{*}{ Giá trị p } \\
\hline & $\begin{array}{l}\text { Không có mảng } \\
\text { bám (Mã số 0) }\end{array}$ & $\begin{array}{l}\text { Có mảng bám } \\
\text { (Mã số 1) }\end{array}$ & & \\
\hline $\begin{array}{l}\text { Không hút } \mathrm{n}(\%) \\
\text { Đang hút } \mathrm{n}(\%)\end{array}$ & $\begin{array}{l}5(6,5) \\
1(2,8)\end{array}$ & $\begin{array}{l}72(93,5) \\
35(97,2)\end{array}$ & $\begin{array}{c}2,43 \\
(0,25-58,9)\end{array}$ & $<0,05$ \\
\hline
\end{tabular}

*Phân tích hồi quy logich

Có mối liên quan giữa tình trạng hút thuốc lá và tình trạng tích tụ mảng bám răng của nhóm đối tượng nghiên cứu với OR (độ tin cậy $95 \%$ ) là 2,43 , nghĩa là trong nhóm đối tượng nghiên cứu, người hút thuốc lá có tình trạng tích tụ mảng bám cao gấp đôi người không hút.

Bảng 3.6. Độ sâu túi quanh răng trung bình và mât bám dính quanh răng trung bình ở nhóm hút thuốc và không hút thuốc

\begin{tabular}{|c|c|c|c|}
\hline & Không hút $\mathbf{( n = 7 7 )}$ & Đang hút (n=36) & Giá trị p \\
\hline $\begin{array}{c}\text { Độ mất bám dính quanh răng } \\
\text { lâm sàng }(\mathrm{X} \pm \mathrm{SD})\end{array}$ & $4,13 \pm 2,38$ & $6,17 \pm 2,83$ & $<0,001$ \\
\hline Độ sâu túi quanh răng $(\mathrm{X} \pm \mathrm{SD})$ & $3,36 \pm 1,65$ & $4,72 \pm 1,91$ & $<0,001$ \\
\hline
\end{tabular}

Độ mất bám dính quanh răng lâm sàng trung bình và độ sâu túi quanh răng trung bình của nhóm hút thuốc lá cao hơn nhóm không hút có ý nghĩa thống kê với $\mathrm{p}<0,001$.

Bảng 3.7. Số vị trí có túi quanh răng sâu trền $5 \mathrm{~mm}$ trung bình ở nhóm hút thuốc và không hút thuốc

\begin{tabular}{|c|c|c|}
\hline Tình trạng hút thuốc & Số vị trí có túi quanh răng $\geq \mathbf{5 m m}$ trung bình & \multirow{2}{*}{ Giá trị p } \\
\hline Không hút $(\mathrm{n}=77)$ & $0,75 \pm 1,57$ & \multirow{2}{*}{$<0,001$} \\
\hline Đang hút $(\mathrm{n}=36)$ & $2,36 \pm 2,57$ & \\
\hline
\end{tabular}

Bảng 3.7 cho thấy các đối tượng trong nhóm hút thuốc lá có số túi quanh răng sâu trên $5 \mathrm{~mm}$ trung bình cao hơn nhóm không hút thuốc có ý nghĩa thống kê với $\mathrm{p}<0,001$.

Bảng 3.8. Mối liên quan giữa độ tuối trên 35 với bệnh viêm quanh răng

\begin{tabular}{|c|c|c|c|c|}
\hline Độ tuổi & $\begin{array}{c}\text { Nhóm bệnh } \\
(\mathbf{N = 7 5}) \mathbf{n}(\mathbf{\%})\end{array}$ & $\begin{array}{c}\text { Nhóm chứng } \\
(\mathbf{N = 3 8 )} \mathbf{n}(\mathbf{\%})\end{array}$ & $\begin{array}{c}\text { OR* (độ tin } \\
\text { cậy 95\%) }\end{array}$ & Giá trị p \\
\hline Độ tuối $\geq 35(\mathrm{~N}=90)$ & $66(88,0)$ & $24(63,2)$ & 4,28 & $<0,01$ \\
\hline Độ tuối $<35(\mathrm{~N}=23)$ & $9(12,0)$ & $14(36,8)$ & $(1,64-11,16)$ & $<0,01$ \\
\hline
\end{tabular}

*Phân tích hồi quy logic

Bảng 3.8 cho thây có mối liên quan giữa độ tuổi trên 35 với bệnh viêm quanh răng ở nhóm đối tượng nghiên cứu với $\mathrm{OR}$ (độ tin cậy $95 \%$ ) là 4,28 và $\mathrm{p}<0,01$. Tỷ lệ người trên 35 tuổi trong nhóm bệnh nhân VQR chiếm 88,0\% và ở nhóm đối tượng có vùng quanh răng lành mạnh là 63,2\%.

\section{BÀN LUẬN}

Nhiều nghiên cứu của các tác giả nước ngoài đã đưa ra các bằng chứng về mối liên quan của hút thuốc lá với tình trạng bệnh quanh răng và coi hút thuốc lá là một yếu tố nguy cơ quan trọng chỉ điểm cho tình trạng mất bám dính và chảy máu lợi. Hiện tượng suy giảm chức năng của hệ thống miễn dịch có thể là một nguyên nhân giải thích cho tỷ lệ mắc bệnh và mức độ trầm trọng cao của VQR ở nhóm đối tượng hút thuốc lá. Ngoài ra một số hóa chất gây độc cho tế bào bạch cầu và đặc biệt là nicotin trong thuốc lá cũng làm ảnh hưởng đến chức năng miễn dịch tại chỗ của cơ thể. Hơn nữa sự thay 
đổi về tình trạng vi khuẩn gây bệnh trong mảng bám dưới lợi ở người hút thuốc lá cũng làm ảnh hưởng đến tình trạng bệnh viêm quanh răng. Kết quả từ nghiên cứu này cho thấy có mối liên quan chặt chẽ của hệ vi khuẩn gây bệnh dưới lợi với tình trạng hút thuốc, đặc biệt là với $A$. actinomycetemcomitans (OR là 7,50). Kết quả này cũng tương tự như kết quả của Winkelhoff A.J (2001) (5). Độ sâu túi quanh răng trung bình và độ mất bám dính quanh răng lâm sàng của nhóm hút thuốc lá cao hơn đáng kể so với nhóm không hút thuốc $(p<0,05)$. Kết quả này phù hợp với kết luận của các tác giả khác (4).

Tình trạng tích tụ mảng bám răng và số lượng túi quanh răng sâu trên $5 \mathrm{~mm}$ của nhóm hút thuốc lá trầm trọng hơn nhóm không hút có ý nghĩa thống kê với $p<0,05$. Điều này cũng phù hợp với kết luận của các tác giả khác và chứng tỏ rằng hút thuốc lá là yếu tố nguy cơ chỉ điểm cho tình trạng trầm trọng của bệnh VQR (3).

Các nhà nghiên cứu cũng thấy rằng mặc dù tốc độ tích tụ mảng bám của người hút thuốc và không hút tương đương nhau, nhưng tốc độ tăng tuần hoàn lợi ở người hút thuốc chỉ bằng một nửa so với người không hút thuốc [3]. Hậu quả là gây ảnh hưởng ngụy trang trên các triệu chứng viêm và có thể dẫn đến kết luận hút thuốc lá không có nguy cơ làm tăng chảy máu lợi. Trong nghiên cứu này, tỷ lệ chảy máu lợi của nhóm không hút thuốc cao hơn nhóm hút thuốc đáng kể $(72,9 \%$ và $27,1 \%)$. Kết quả này phù hợp với kết quả nghiên cứu của Van der Weijden và công sứ (2001) là không có sự khác biệt về mức độ chảy máu lợi giữa nhóm hút thuốc và không hút thuốc măcc dù nhóm hút thuốc có có túi lợi sâu hơn hoặc tích tụ nhiều mảng bám hơn[5].
Nhiêu nghiên cứu cho thấy, người mắc viêm quanh răng thường già hơn và là nam giới (6). Nhận xét này cũng phù hợp với kết quả của nghiên cứu này. Tỷ lệ mắc bệnh của người trên 35 tuổi cao hơn đáng kể so với lứa tuối trẻ hơn với $O R$ (độ tin cậy $95 \%$ ) là 4,25 và $p<0,01$. Tuy nhiên, có thể chính sự phơi nhiễm với các yếu tố nguy cơ trong một thời gian dài đó làm tăng tỷ lệ mắc bệnh VQR ở người cao tuổi.

\section{KẾT LUẬN}

Các yếu tố nguy cơ như sự có mặt của một số vi khuẩn gây bệnh, tình trạng hút thuốc lá, tuổi...có liên quan chăăt chẽ với sự khởi phát và tiến triển của bệnh viểm quanh răng. Những yếu tố này có thể được coi là yếu tố chỉ điểm cho mức độ trầm trọng của bệnh VQR và được sử dụng để tiên lượng cho kết quả điều trị bệnh.

\section{TÀI LIẸU THAM KHẢO}

1. American Academy of Periodontitis (2000) "Parameter on Chronic periodontitis with advanced loss of periodontal support", J. Periodontol, 71, pp. 856-858.

2. Martha E.N. (2003), "Understanding the etiology of periodontitis: an overview of periodontal risk factors", Periodontology 2000, 32, pp. 11-23.

3. Armitage G.C (2004), "Periodontal diagnoses and classification of periodontal diseases", Periodontology 2004, Vol. 34, pp. 9-21.

4. Rivera-Hidalgo F. (2003), "Smoking and periodontal disease", Periodontology 2000, Vol.32, pp. 50-58.

5. Van Winkelhoff A., Bosch-Tijhof C.J., Winkel E.G., Van der Reijden W.A. (2001), "Smoking affects the Sub-gingival Microflora in Periodontitis", J. Periodontol, 72, pp. 666-671.

6. Torrungruang $K$, Bandhaya $P$ et al (2009), "Relationship between the presence of certain bacteria pathogens and periodontal status of urban Thai adults", J periodontol 2009;80:122-129.

\section{MộT Số YẾU Tố LIÊN QUAN ĐẾN HIỆU QUẢ CỦA ATOSIBAN TRONG ĐIỀU TRI DỌA ĐỂ NON TẠI BỆNH VIỆN PHỤ SẢN TRUNG ƯƠNG}

Nguyễn Mạnh Thắng*

\section{TÓM TẮT}

Mục tiêu: Mô tả một số yếu tố liên quan đến hiệu quả giảm co của Atosiban trong điêu trị dọa đẻ non tại Bệnh viện Phụ sản Trung Ương. Đối tượng và phương pháp: Nghiên cứu mô tả, hồi cứu nhằm mô

*Trường Đại học Y Hà Nội

Chịu trách nhiệm chính: Nguyễn Mạnh Thắng

Email: bsnguyenmanhthang@gmail.com

Ngày nhận bài: 2/4/2021

Ngày phản biện khoa học: 16/4/2021

Ngày duyệt bài: 19/5/2021 tả một số yếu tố liên quan đến hiệu quả giảm co của Atosiban trong điều trị dọa đẻ non ở thai phụ. Kết quả: Trẻ có cân nặng lúc sinh càng cao thì tỷ lệ điều trị thành công càng tăng $(p<0,05)$, Chỉ số Apga trong nhóm $>7$ tại phút thứ nhất và thứ 5 có tỷ lệ điều trị thành công cao hơn $(p<0,05)$, sản phụ nhập viện điều trị sớm hơn có tỷ lệ điêu trị thành công cao hơn $(p<0,05)$. Kết luận: Kết quả sẽ này góp phần quan trong trong việc định hướng điều trị của các bác sĩ lâm sàng.

Tư khóa: Đẻ non, Atosiban, Yếu tố liên quan

SUMMARY 